\title{
COVID-19 Lockdown Home Gardening in the Western Province of Sri
}

\section{Lanka}

\section{T.G.U.P. Perera"1, N.C. Wickramaarachchi'², H.M.L.P. Karunarathne ${ }^{3}$, Lasika Madhawa Munasinghe ${ }^{4}$, Kasuni Rupasinghe ${ }^{5}$}

\section{Abstract}

Sampling a set of households from three districts of the Western Province, this paper explored the landscape of lockdown home gardening which took place during the first wave of the COVID-19 pandemic in Sri Lanka. A structured questionnaire published online enabled collecting 939 household responses. A descriptive analysis performed using the IBM SPSS package highlights that the lockdown conditions have intensified the level of home gardening of the participants. The study validates the findings from recent studies that home gardening has no dividing line when it comes to the socioeconomic character of households. Primary benefit of home gardening is of households' being in seek of good and healthy consumption, vegetables and fruits have been the most preferred crop types to grow. Application of organic fertiliser have been preferred by the majority of the households. This study supports the notion that urban land scarcity is not a limiting factor for home gardening. The paper suggests that this home gardening trend reignited during the Covid-19 lockdown needs to be supported by three means: promoting healthy lifestyles, connecting government officials with local home gardeners and local plans being supportive and appreciative of home gardening.

Keywords: Lockdown Home Gardening, COVID-19, Urban Agriculture, Gardener Engagement, Benefits, Challenges, Sri Lanka
Department of Estate Management and Valuation, Faculty of Management Studies and Commerce, University of Sri Jayewardenepura, Sri Lanka

tgup@sjp.ac.lk

(ㄱ) 1 https://orcid.org/0000-00022092-9197

(17) 2 https://orcid.org/0000-0002$8206-1514$

(17) ${ }^{3}$ https://orcid.org/0000-00026067-7203

(10) 4 https://orcid.org/0000-00021051-6110

(D) ${ }^{5}$ https://orcid.org/0000-0002$\underline{7042-4285}$

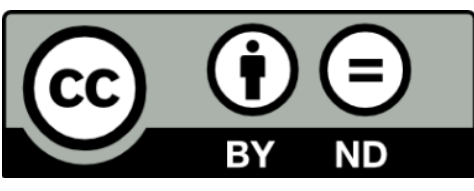

This article is published under the Creative Commons CC-BY-ND License (https://creativecommons.org/licenses/by-nd/4.0/). This license permits to use, distribute, and reproduce the contents of the publication for commercial and non-commercial purposes, provided that the original work is properly cited and is not changed anyway. 


\section{Original Article}

\section{INTRODUCTION}

COVID-19 is a novel infectious respiratory disease that emerged in Wuhan, Hubei province, China, in 2019 and was caused by a class of Coronavirus, known as SARS-CoV-2 (Severe Acute Respiratory Syndrome Coronavirus 2) (World Health Organization (WHO), 2020a). It has become a pandemic that is instantaneously causing an unprecedented impact on human health (Worldometer, 2021). In this scenario, countries took different measures to control the transmission of the virus by quarantining, testing and treating people, partial or complete lockdowns, social distancing, etc. (Verma and Prakash, 2020; WHO, 2020b). Sri Lanka also experienced an island-wide curfew in which the first wave lockdown took place from March to July 2020 (Department of Government Information, 2020).

The pandemic and lockdown conditions have created a vibrant movement towards promoting and implementing home gardening worldwide (see, for example, FAO, 2020; Walljasper and Polansek, 2020). Sri Lankans also started showing a heightened interest in cultivation and started growing foods, leading to the lockdown home gardening boom in Sri Lanka (Rodrigo, 2020). Further, amid this unprecedented lockdown time, knowing the benefits that can bring to society, the Sri Lankan government also promoted the public to engage in home gardening and launched several programs in support of that. An example of this is the "Saubagya" National Program on Harvesting and Cultivation, initiated in early April 2020 to develop one million home gardens. Moreover, individuals, community groups, NonGovernmental Organisations (NGOs), private institutes promoted the home gardening concept through social media platforms (e.g., Facebook pages, YouTube channels and Television programs).

Home gardening is often considered to be an element of urban agriculture (Badami and Ramankutty, 2015; Lal, 2020) and generally promoted as a solution to food insecurity, even before COVID-19 (Galhena, 2012; Yapa, 2018). As per the 2019 statistics, 135 million people from 55 countries and territories struggle with food insecurity (Global Report on Food Crisis, 2020). COVID19 compounds a 'crisis within a crisis' which leads to a severe food crisis due to the pandemic (Fan, 2020; FAO, 2020; Hossain, 2020). In this respect, lockdown home gardening became a partial or complete way of surviving the households with day-to-day food requirements with fresh and nutritious foods. Besides, that also gained them some form of income security, reducing mental stress and psychological burden, as well as a productive way of spending quality time with the family, way of getting physical exercise (Lal, 2020; Sofo and Sofo, 2020). The boom of lockdown home gardening in urban areas of Sri Lanka and its benefits for 


\section{Original Article}

social wellbeing were explained in various literature (Dissanayake and Dilini, 2020; Rodrigo, 2020). However, limited attention has been given to depict the landscape of lockdown home gardening and people's engagement, particularly in the Western Province, which is the area that has been subjected to the longest lockdown, being the highly affected area in the country.

With this purview, we adapt the meaning of lockdown home gardening as a small-scale cultivation system around a family dwelling or within walking distance of a family dwelling that consists of mixed crops such as vegetables, fruits, flowers, medicinal plants, and livestock that initiate or reinitiate during the period of complete lockdown due to COVID-19 pandemic (Galhena et al., 2013; Al-Mayahi et al., 2019). This research aims to study the landscape of lockdown home gardening in the Western Province of Sri Lanka, which particularly took place from March to July 2020; the first wave of the COVID-19 pandemic in Sri Lanka. Accordingly, the study focuses on the following three broad aspects: characteristics of the gardener, characteristics of lockdown home gardening, and benefits, challenges and suggestions. The study used an online survey approach. A structured questionnaire developed by Google Forms was used as the data collection instrument. Data were analysed using descriptive statistics processed by the IBM SPSS package. The rest of the paper is organised as follows. First, it discusses the literature related to lockdown home gardening. Secondly, the paper informs about the study methods. Finally, the paper discusses the empirical results related to the three broad aspects of lockdown home gardening. This research may warrant empirical addition to the contemporary home gardening literature. In addition, the results can be used for policies related to promoting urban agriculture and sustainable resilient cities. Moreover, it provides insights to shape urban areas with respect to Sustainable Development Goal 2- zero hunger and Sustainable Development Goal 11 Sustainable Cities and Communities.

\section{LITERATURE REVIEW}

\section{Home gardening}

Despite no universally accepted definition, the scholars commonly define home garden as a microenvironment situated close to the homestead (Nifiez, 1987; Watson and Eyzaguirre, 2002) where several species of plants are grown and maintained by the household members and their products are primarily intended to the family consumption. It can be a multipurpose garden that comprises diversified species of crops (annual or perennial, root crops to climbers etc.,) and livestock (Watson and Eyzaguirre, 2002; Kehlenbeck and Maass, 2004; Galhena et al., 2013; Al-Mayahi et al., 2019). Home gardening is also recognised as 'homestead garden', 


\section{Original Article}

'backyard garden', 'kitchen garden', 'agroforestry', 'mixed garden', etc. (Helen Keller international, 2001; Mictchell and Hanstad 2004).

Home garden is the most common form of urban agriculture around urban environments (Zasada et al., 2020). As a supplementary food source, home gardening becomes more vital when there is a distraction of access to fresh food in urban areas (Altieri and Nicholls, 2020) in conditions such as the COVID-19 pandemic. Home gardening is accepted as a means to strengthen local agricultural growth and cities to have a more resilient food system (Zasada et al., 2020). In this light, lockdown home gardening emerged as a critically important notion to strengthen local food production at the household and community levels, particularly during Covid-19 pandemic conditions (Dissanayake and Dilini, 2020; Lal, 2020; Montefrio, 2020; Rodrigo, 2020; Sofo and Sofo, 2020). This home gardening trend that emerged during the lockdown has been investigated under many aspects in different studies (e.g., Dissanayake and Dilini, 2020; Sofo and Sofo, 2020; Talidong and Toquero, 2020; Corley et al., 2021; Mullins et al., 2021). Adding more empirical evidence to such investigations, this study investigated the landscape of lockdown home gardening in the Western Province in Sri Lanka during the first wave of the pandemic by focusing on three broad aspects: (i) characteristics of home gardener, (ii) characteristics of lockdown home gardening and benefits, (iii) challenges and suggestions of home gardening (Figure $1)$.

\section{Home Gardener}

Gardener here refers to the person in the household often spending more time in the garden (Gray et al., 2014). In terms of experimenting the socioeconomic character of gardeners, home gardening and urban agriculture literature often discuss the contribution levels and preferential differences between men and women in the household. For instance, some scholars argued whether home gardening had become a women-centric activity in the household (e.g., Abebe and Mulu, 2017; Dissanayake and Dilini, 2020). Robertson (2013) stated that even though both men and women engage in urban agriculture for the same reasons, women receive an additional benefit of stress relief from participating in the gardens. ReyesGarcía et al., (2010); Taylor et al., (2016) and Philpott et al. (2020) have observed that women are more likely to cultivate ornamental and medicinal plants, whereas men are more likely to grow vegetables than ornamental crops. Moreover, it was also found that the friends and family support that gardeners receive would have a positive impact on home gardening in terms of cultivating more varieties and looking after them (Gray et al., 2014; Zasada et al., 2020). Some literature has also looked into the educational level of gardens and has discovered that those 


\section{Original Article}

who are with less formal education (no more than high school) spent about twice as much on gardening compared to those with more formal education (at least some post-high school education) (Philpott et al. 2020). This articulation has changed in the current literature on COVID-19 lock down home gardening. Gardeners of lockdown home gardening have been from all employment levels, educational backgrounds, social levels and has been indifferent between men and women (see for example, Dissanayake and Dilini, 2020; Montefrio, 2020; Rodrigo, 2020; Talidong and Toquero, 2020; Walljasper and Polansek, 2020).

\section{Characteristics of home gardening}

The empirical research on home gardening reveals that lockdown has not compromised on crop varieties possible to grow in home gardening. Under lockdown conditions, households have been able to grow crop types such as vegetables, fruits, medicinal herbs, officinal plants, and spices (Sofo and Sofo, 2020; Walljasper and Polansek, 2020; Mullins et al., 2021; Rodrigo, 2020). The smart and innovative cultivation techniques that the gardeners use such as high beds, hanging boxes and buckets in small vacant areas such as balcony, terrace, and small courtyard (Al-Mayahi et al., 2019; Sofo and Sofo, 2020; Zasada et al., 2020) have helped them to cultivate a range of crops even in the land plots that are very small or apartments that do not have a land to grow. It was also notable that lockdown home gardening mostly used organic fertilisers (Dissanayake and Dilini, 2020; Montefrio, 2020; Walljasper and Polansek, 2020; Zasada et al., 2020). Besides, the study that has been conducted in Kandy, Sri Lanka has shown that during the lockdown time, people have been sharing organic fertiliser produced in their homes among neighbours or supportive parties (Dissanayake and Dilini, 2020). By handling a large variety of crops, organic fertiliser usage, cultivation techniques and giving more environmental focus, people have created their gardens as biodiversity hubs (Zasada et al., 2020). In a similar vein, Walljasper and Polansek (2020), in their review regarding home gardening boom around the world during the pandemic, have highlighted that households have reached to neighbouring gardens to avoid crop overlaps so that they can share different crop productions. Further, it was found that lockdown home gardening outputs have made a great contribution to monthly household consumption (Mullins et al., 2021).

\section{Benefits and Challenges of home gardening}

Motivations for home gardening are strongly connected with the benefits coming through home gardening. More broadly, home gardening delivers different types of social, economic, and environmental benefits. Social benefits that home gardening can deliver are enhancing food security (Thaman, 1995; Galhena et al., 2013; Rajani and 


\section{Original Article}

Joshi, 2017), improving physical and mental health (Galhena, et al., 2013; Dissanayake and Dilini, 2020; Corley et al., 2021; Mullins, et al., 2021), women empowerment (Bushamuka et al., 2005; Galhena et al., 2013) and selfsatisfaction (Sofo and Sofo, 2020). From an economic point of view home gardening provides livelihood opportunities (Kehlenbeck and Maass, 2004; Mitchell and Hanstad, 2004; Galhena et al. 2013; Badami and Ramankutty, 2015; Zasada et al., 2020), savings on household's cost for food (Kehlenbeck and Maass, 2004; Sofo and Sofo, 2020), promoting local entrepreneurship and rural development (Galhena et al. 2013) and creates disposable income for other domestic needs of the household such as health and education of children (Badami and Ramankutty, 2015). The environmental or ecosystem improving benefits of home gardening are improving soil fertility in home gardens (Calvet-Mir et. al., 2012), water purification (Calvet-Mir et. al., 2012) and enhance the quality of the environment (Kehlenbeck and Maass, 2004; Buchmann, 2009; Calvet-Mir et. al., 2012; Dissanayake and Dilini, 2020). Out of many benefits, home gardening during lockdown highlighted its contribution to the improvement of the mental health of gardeners (Dissanayake and Dilini, 2020; Corley et al., 2021; Mullins et al., 2021).
Along with such a wider range of benefits, executing home gardening also has its key challenges. Some notable challenges highlighted in the empirical studies in the context of different regions and countries such as Oman (Al-Mayahi et al., 2019), Asia (Hoogerbrugge and Fresco, 1993; Mitchell and Hanstad, 2004; Dissanayake and Dilini, 2020), Mesoamerica (Howard, 2006), South Africa (Adekunle, 2014) and Peru (Niñez, 1985) are lack of land availability for cultivation (Hoogerbrugge and Fresco, 1993; Howard, 2006; Al-Mayahi et al., 2019), limited access to agricultural inputs such as seeds, tools etc.(Adekunle, 2014), lack of knowledge (Adekunle, 2014; Al-Mayah, et al., 2019; Dissanayake and Dilini, 2020), poor soil fertility and soil erosion (Howard, 2006; Al-Mayahi, et al., 2019), difficulties in access to water (Niñez, 1985), threats from pest, diseases and theft (Niñez, 1985; Dissanayake and Dilini, 2020) and lack of opportunities to access quality livestock breeds (Mitchell and Hanstad, 2004).

According to this comprehensive literature review, this study frames the landscape of lockdown home gardening into three broad aspects and further catergorised into ten sub aspects. (Figure 1). 


\section{Original Article}

Figure 01. Aspects to examine in understanding the landscape of lockdown home gardening

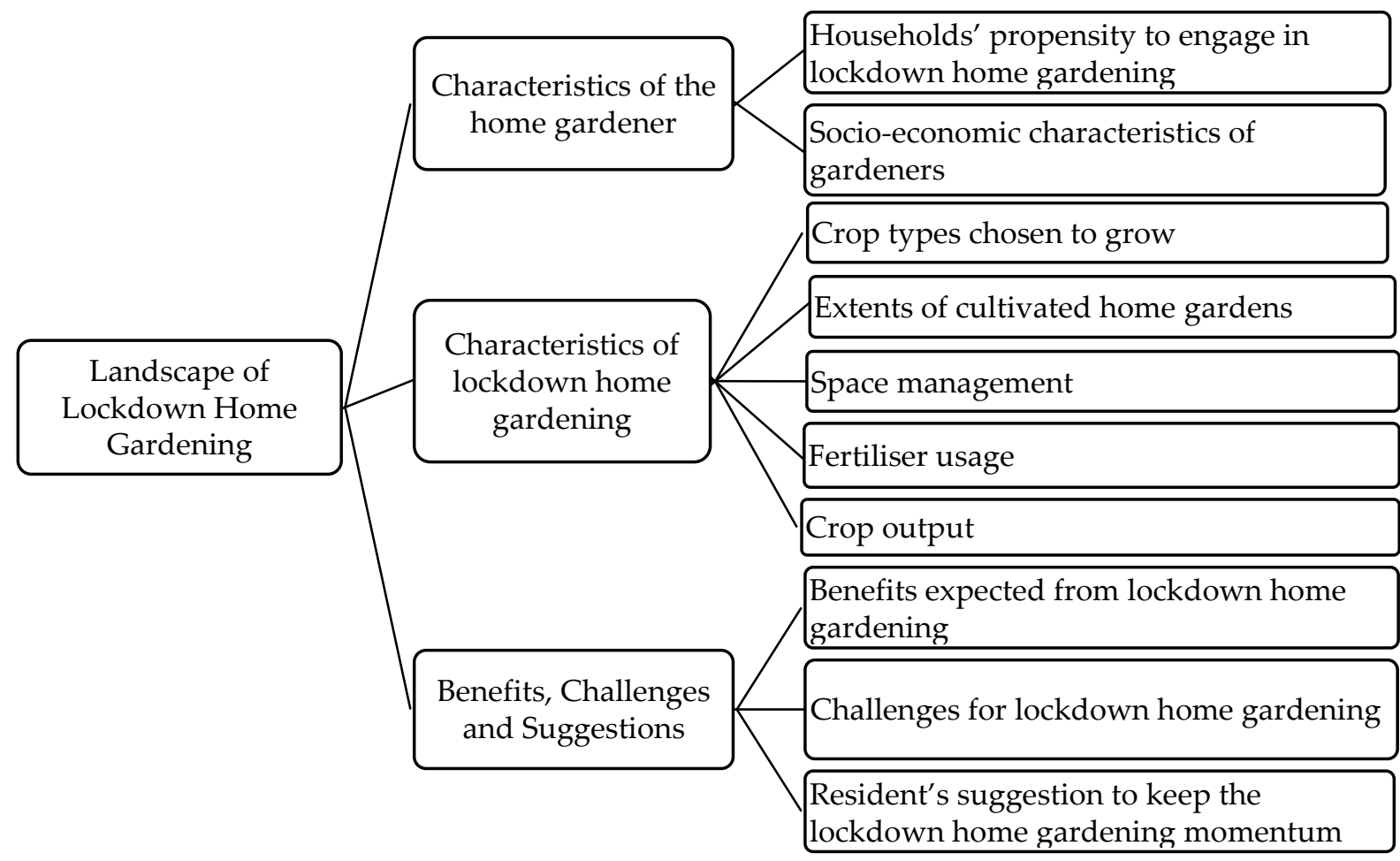

Source: Compiled by Authors, 2021

\section{METHODS AND MATERIAL}

\section{Study area}

The study was carried out in the Western Province of Sri Lanka, which encompasses three urbanised ${ }^{1}$ districts; Colombo, Gampaha and Kaluthara (Figure 02). The Western Province span over an extent of 368,400 hectares falls within the wet zone ${ }^{2}$ of Sri Lanka. The total number of households in the Western Province is 1,482,221, i.e., 28.2 per cent of Sri Lanka's household population (Department of Census and

\footnotetext{
${ }^{1}$ Entire area of all three districts is declared as urban promotion areas by the Urban Development Authority Sri Lanka
}

Statistics, 2012). Being the highest urbanised region of the country, the Western Province provides the highest contribution to GDP (39.1 per cent) (Central Bank of Sri Lanka, 2019), consisting of $9.7 \%$ agricultural sector contribution. The home garden land use of the Western Province is around $36.63 \%$ (Department of Land Use Planning Office, 2018), out of which the shares for Colombo, Gampaha and Kaluthara districts are $37.77 \%, 48.56 \%$ and $27.65 \%$, respectively. During the first wave of the Covid-19, the Western

\footnotetext{
2 The average annual temperature in the province ranges from $26.0-27.0^{\circ} \mathrm{C}$, whilst the annual rainfall records to be 2348 - $3141 \mathrm{~mm}$ (Department of Meteorology, 2021)
} 


\section{Original Article}

Province underwent the longest lockdown with travel bans enforced between the period of $20^{\text {th }}$ March to $11^{\text {th }}$ May 2020 compared to the rest of the country, whilst the gradual normalising of daily activities went on till the end of July 2020. During such time, all households were confined to their houses with strict mobility restrictions whilst they had limited access to goods and services (Weerahewa et al., 2020; Hettiarachchi et al., 2021). However, it is noteworthy here that such lockdown measure was enforced as a precautionary measure to control the spread of the virus ${ }^{3}$. Thus, it is fair to assume that the public in general had mental and physical stability to engage in home gardening should they be willing to do so.

Figure 02. Map of Western Province of Sri Lanka

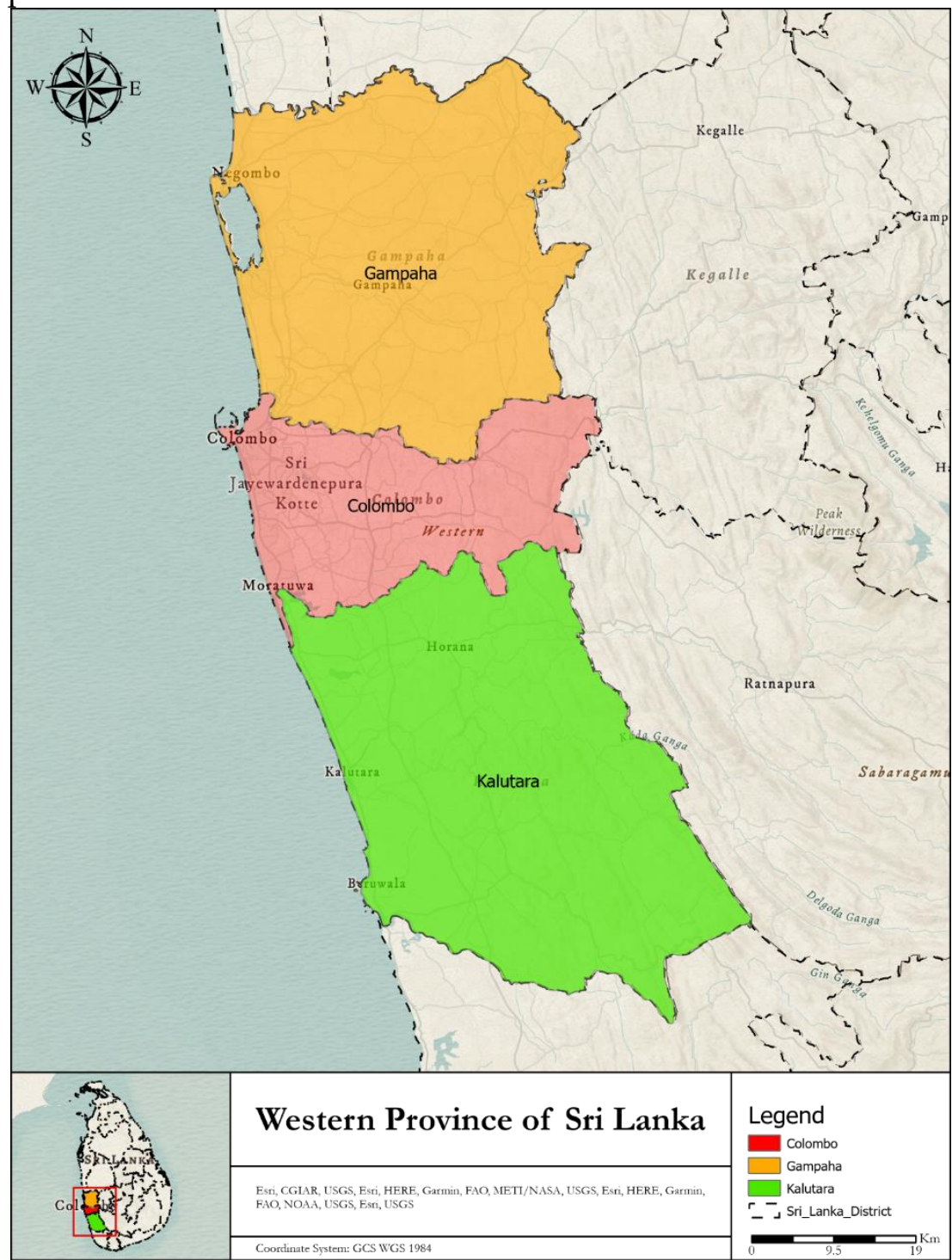

Source: Compiled by Authors, 2021

\footnotetext{
${ }^{3}$ There were only 73 confirmed Covid 19 cases at the time of $1^{\text {st }}$ Lockdown ( $20^{\text {th }}$ March 2020)
} 


\section{Original Article}

Data collection and analysis

The focus of the study was to understand the home gardening landscape in the Western Province of Sri Lanka under the lockdown conditions. Accordingly, the data collection of the study adapted the online questionnaire survey with convenience sample approach, which enabled reaching the household respondents in the Western Province under lockdown conditions. Such study methods are seemingly deemed appropriate when looking into contemporary studies of similar investigations (see for example, Bidarbakhtnia, 2020; R Nair et al., 2020; Rossi et al., 2020).

The questionnaire was prepared by an extensive review of home gardening literature (Table 01) and with the consultation of a group of experts in the field. To collect data on three (03) main aspects and ten (10) sub aspects as shown in Figure 01, the questionnaire was structured into four sections. The first section consisted of filtering questions to ensure that the respondents were from the Western Province. The rest of the three sections focused on (i) respondents' background information and household propensity to engage in lockdown home gardening, (ii) characteristics of lockdown home gardening and (iii) benefits, challenges and suggestions to improve home gardening in the Western Province. The first three parts of the questionnaire and the question related to the "benefits of home gardening" were based on Multiple Choice Questions (MCQs). The answers for them were structured based on the literature review and expert opinions. In addition, the answers included "Other (Please State)" option to capture respondents own answers that may not have been covered within the structured answers. With a view to provide better insights regarding the "challenges for home gardening" the structured answers given for MCQ used a Likert scale of three ( $1=$ challenge is not relevant, $2=$ challenge is relevant, and $3=$ challenge is highly relevant). In addition, the questionnaire included an open-ended question to receive respondents' "suggestions to improve home gardening in the Western Province".

A pilot survey with 50 participants was conducted through email to refine the questionnaire, and slight revisions were made to the wordings and flow of questions based on the initial findings. Following the convenience sampling method, the questionnaire was open to the entire households in the Western Province who would be interested to self-report. In order to recruit the highest possible respondent rate, the questionnaire was made available in Sinhala, Tamil, and English languages and was widely published on several government websites and social media groups. The questionnaire was available online and was valid to respond from $15^{\text {th }}$ May to $07^{\text {th }}$ September 2020, and the total number of responses received to the 


\section{Original Article}

questionnaire was 939 households: 459 were from the Colombo district, 254 were from the Gampaha district, and 226 were from the Kalutara district.

Given that the focus of the study is to explain the landscape of lockdown home gardening, descriptive statistics (processed through the IBM SPSS package) was fitted to analyse data. Accordingly, data were presented through tables and charts as appropriate. The resident's perception on challenges for home gardening measured using the Likert Scale recorded a Cronbach Alpha (reliability value) of 0.966 (Table 02). Qualitative data collected for the open-ended question: "households' suggestions to improve home gardening" followed a content analysis.

A key limitation of the study is that the respondents were restricted to those with internet access and digital literacy, resulting in an inherent coverage bias.

Table 01. Structure of the Questionnaire

\begin{tabular}{|c|c|c|}
\hline $\begin{array}{c}\text { Main } \\
\text { Aspects }\end{array}$ & $\begin{array}{c}\text { Key question } \\
\text { area }\end{array}$ & $\begin{array}{l}\text { Question } \\
\text { type }\end{array}$ \\
\hline \multirow{2}{*}{$\begin{array}{l}\text { Characteristi } \\
\text { cs of the } \\
\text { Home } \\
\text { gardener }\end{array}$} & $\begin{array}{l}\text { Household } \\
\text { propensity to } \\
\text { engage in } \\
\text { lockdown } \\
\text { home } \\
\text { gardening }\end{array}$ & $\begin{array}{c}\text { Multiple } \\
\text { Choice }\end{array}$ \\
\hline & $\begin{array}{l}\text { Socio- } \\
\text { economic } \\
\text { characteristics } \\
\text { of gardeners } \\
\text { (Mullins et al., } \\
\text { 2021, Sofo and } \\
\text { Sofo, 2020, }\end{array}$ & $\begin{array}{c}\text { Multiple } \\
\text { Choice }\end{array}$ \\
\hline
\end{tabular}

Corley et al., 2021,

Talidong and

Toquero,

2020,

Dissanayake and Dilini, 2020)

\begin{tabular}{|c|c|c|}
\hline \multirow{4}{*}{$\begin{array}{l}\text { Characteristi } \\
\text { cs of } \\
\text { Lockdown } \\
\text { Home } \\
\text { gardening }\end{array}$} & $\begin{array}{l}\text { Crop types } \\
\text { chosen to } \\
\text { grow } \\
\text { (Dissanayake } \\
\text { and Dilini, } \\
\text { 2020, Sofo and } \\
\text { Sofo, 2020; } \\
\text { Walljasper } \\
\text { and Polansek, } \\
\text { 2020; Mullins } \\
\text { et al., 2021; } \\
\text { Rodrigo, } \\
\text { 2020) }\end{array}$ & $\begin{array}{l}\text { Multiple } \\
\text { Choice }\end{array}$ \\
\hline & $\begin{array}{l}\text { Extents of } \\
\text { cultivated } \\
\text { home gardens } \\
\text { (Watson and } \\
\text { Eyzaguirre, } \\
\text { 2002; } \\
\text { Kehlenbeck } \\
\text { and Maass, } \\
\text { 2004; Galhena } \\
\text { et al., 2013; } \\
\text { Al-Mayahi et } \\
\text { al., 2019) }\end{array}$ & $\begin{array}{c}\text { Multiple } \\
\text { Choice }\end{array}$ \\
\hline & $\begin{array}{l}\text { Space } \\
\text { management } \\
\text { (Dissanayake } \\
\text { and Dilini, } \\
\text { 2020; Sofo and } \\
\text { Sofo, 2020; } \\
\text { Zasada et al., } \\
\text { 2020) }\end{array}$ & $\begin{array}{l}\text { Multiple } \\
\text { Choice }\end{array}$ \\
\hline & $\begin{array}{l}\text { Fertiliser } \\
\text { usage } \\
\text { (Dissanayake } \\
\text { and Dilini, }\end{array}$ & $\begin{array}{c}\text { Multiple } \\
\text { Choice }\end{array}$ \\
\hline
\end{tabular}




\section{Original Article}

\begin{tabular}{|c|c|c|}
\hline & $\begin{array}{l}\text { 2020; } \\
\text { Montefrio, } \\
\text { 2020; } \\
\text { Walljasper } \\
\text { and Polansek, } \\
\text { 2020; Zasada } \\
\text { et al., 2020) }\end{array}$ & \\
\hline & Crop output & $\begin{array}{c}\text { Multiple } \\
\text { Choice }\end{array}$ \\
\hline \multirow{3}{*}{$\begin{array}{l}\text { Benefits, } \\
\text { Challenges } \\
\text { and } \\
\text { suggestions }\end{array}$} & $\begin{array}{l}\text { Benefits } \\
\text { expected from } \\
\text { lockdown } \\
\text { home } \\
\text { gardening } \\
\text { (Kehlenbeck } \\
\text { and Maass, } \\
\text { 2004; } \\
\text { Buchmann, } \\
\text { 2009; Calvet- } \\
\text { Mir et. al., } \\
\text { 2012; } \\
\text { Dissanayake } \\
\text { and Dilini, } \\
\text { 2020) }\end{array}$ & $\begin{array}{c}\text { Multiple } \\
\text { Choice }\end{array}$ \\
\hline & $\begin{array}{l}\text { Challenges } \\
\text { for lockdown } \\
\text { home } \\
\text { gardening } \\
\text { (Hoogerbrugg } \\
\text { e \& Fresco, } \\
\text { 1993; Soini, } \\
\text { 2005; Sunwar } \\
\text { et al., 2006) }\end{array}$ & $\begin{array}{c}\text { Multiple } \\
\text { Choice with } \\
\text { Likert Scale }\end{array}$ \\
\hline & $\begin{array}{l}\text { Resident's } \\
\text { suggestion to } \\
\text { keep the } \\
\text { lockdown } \\
\text { home } \\
\text { gardening } \\
\text { momentum }\end{array}$ & $\begin{array}{l}\text { Open- } \\
\text { Ended }\end{array}$ \\
\hline
\end{tabular}

Table 02. Reliability Statistics

\begin{tabular}{ccc}
$\begin{array}{c}\text { Cronbach's } \\
\text { Alpha }\end{array}$ & $\begin{array}{c}\text { Cronbach's Alpha } \\
\text { Based on Standardised } \\
\text { Items }\end{array}$ & $\begin{array}{c}\mathrm{N} \text { of } \\
\text { Items }\end{array}$ \\
\hline .966 & .967 & 24 \\
\hline
\end{tabular}

Source: Compiled by Authors, 2021

\section{ANALYSIS}

\section{Characteristics of gardeners}

Households' propensity to engage in lockdown home gardening

The 939 respondents showed (Table 3) that at least $75 \%$ of households from all three districts in the Western Province were already engaged in some level of home garden cultivation even before the area went under lockdown. At least $95 \%$ of them from all three districts were interested to continue and intensify cultivations in gardens furthermore. Only a total of $22 \%$ from all three districts in the Western Province had not been engaged in home gardening before the lockdown. Lockdown conditions seem to have driven $89 \%$ of them to enter into home gardening. Accordingly, among these 939 respondents, the new entry to the home gardening due to lockdown conditions would be $22.31 \%$ from Colombo, 19\% from Gampaha and 16\% from Kaluthara, amounting to $28.48 \%$ from the Western Province.

Source: Compiled by Authors, 2021 


\section{Original Article}

Table 03. Likeness to engage in home gardening

Likeness for home gardening

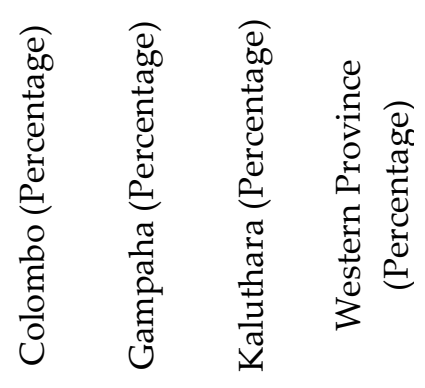

Engaged in

home gardening

before the

lockdown

\begin{tabular}{lcccc} 
Yes & 77 & 81 & 75 & 78 \\
$\begin{array}{l}\text { Likeness to } \\
\text { intensify the } \\
\text { level of existing } \\
\text { home gardening } \\
\text { during the } \\
\text { lockdown }\end{array}$ & & & & \\
\multicolumn{1}{l}{ Yes } & 99 & 100 & 95 & 98 \\
No & 1 & 0 & 5 & 2 \\
\hline
\end{tabular}

Engaged in

home gardening

before the

lockdown

$\begin{array}{lllll}\text { No } & 23 & 19 & 25 & 22\end{array}$

Likeness to start

home gardening

as a result of

the lockdown

\begin{tabular}{ccccc} 
Yes & 97 & 100 & 64 & 89 \\
No & 3 & 0 & 36 & 11 \\
\hline
\end{tabular}

Source: Field survey, 2020

\section{Socio-economic characteristics of home gardeners}

As Table 04 highlights, the respondents who participated in lockdown home gardening were recorded to be $42 \%$ male and $58 \%$ female. They were also households of all ages from 16 to more than 64. The majority of the participants had one or more higher educational qualifications. The households engaged in home gardening were also a mix in terms of their occupational backgrounds government, private, casual, selfemployed, retired or unemployed status. Many of the respondents were spending between LKR 25,000-50000/(USD 138 - 277 equivalent) per month on food, and the size of their households was primarily 4-6 members.

Table 04. Socio-economic characteristics of the households engaged in lockdown home gardening

\begin{tabular}{|c|c|c|c|c|}
\hline $\begin{array}{l}\text { Socio-economic } \\
\text { characteristics of } \\
\text { the households } \\
\text { engaged in } \\
\text { lockdown home } \\
\text { gardening }\end{array}$ & 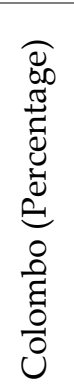 & 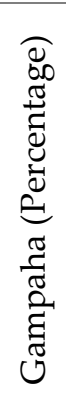 & 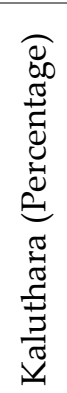 & 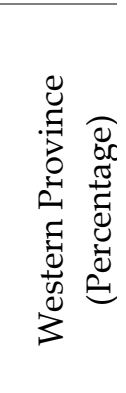 \\
\hline
\end{tabular}

\begin{tabular}{lcccc}
\hline Gender & & & & \\
\hline Male & 45 & 43 & 35 & 42 \\
Female & 55 & 57 & 65 & 58 \\
\hline Age & & & & \\
\hline $16-24$ & 15 & 45 & 51 & 32 \\
$25-44$ & 60 & 29 & 31 & 44 \\
$45-64$ & 23 & 23 & 18 & 22 \\
Over 64 & 2 & 2 & 0 & 4 \\
\hline Level of & & & & \\
Education & & & & \\
\hline $\begin{array}{l}\text { Higher } \\
\text { educational }\end{array}$ & 40 & 54.3 & 37 & 43.2 \\
qualifications & & & & \\
(PhD, Masters, & & & & \\
$\begin{array}{l}\text { Postgraduate } \\
\text { Diploma, }\end{array}$ & & & & \\
Bachelors) & & & & \\
Diploma or & 11 & 15.2 & 7 & 11.0 \\
certificate & & & & \\
programs & & & &
\end{tabular}




\section{Original Article}

\begin{tabular}{|c|c|c|c|c|}
\hline $\begin{array}{l}\text { Higher } \\
\text { secondary } \\
\text { school (Advance } \\
\text { level or } \\
\text { equivalent) }\end{array}$ & 22 & 20.1 & 47 & 27.5 \\
\hline $\begin{array}{l}\text { Secondary } \\
\text { school } \\
\text { (Ordinary level } \\
\text { or equivalent) }\end{array}$ & 23 & 9.8 & 9 & 16.0 \\
\hline Primary School & 3 & 0.6 & 0 & 1.9 \\
\hline Prefer not to say & 1 & 0 & 0 & 0.4 \\
\hline \multicolumn{5}{|l|}{ Occupation } \\
\hline $\begin{array}{l}\text { Government/Pu } \\
\text { blic sector }\end{array}$ & 27 & 17 & 15 & 21.4 \\
\hline Private sector & 39 & 25 & 30 & 33 \\
\hline $\begin{array}{l}\text { Daily wage } \\
\text { worker }\end{array}$ & 3 & 1 & 2 & 2.3 \\
\hline Self-employed & 13 & 7 & 5 & 9.5 \\
\hline Retired & 3 & 2 & 1 & 2.3 \\
\hline Unemployed & 1 & 8 & 8 & 4.8 \\
\hline Student & 13 & 39 & 38 & 26.3 \\
\hline $\begin{array}{l}\text { Other (eg: } \\
\text { independent } \\
\text { researcher and } \\
\text { Semi- } \\
\text { government } \\
\text { University) }\end{array}$ & 1 & 0 & 0 & 0.3 \\
\hline
\end{tabular}

\begin{tabular}{lcccc}
\hline $\begin{array}{l}\text { Number of } \\
\text { family members }\end{array}$ & & & & \\
\hline 1 to 3 & 26 & 21 & 15 & 22.1 \\
4 to 6 & 72 & 77 & 82 & 75.9 \\
7 to 9 & 1 & 2 & 2 & 1.9 \\
10 or above & 0 & 0 & 1 & 0.1 \\
\hline $\begin{array}{l}\text { Average } \\
\text { monthly } \\
\text { expenditure on }\end{array}$ & & & & \\
food & & & & \\
\hline $\begin{array}{l}\text { Less than } \\
\text { LKR.25000 }\end{array}$ & 13 & 50 & 36 & 29 \\
$\begin{array}{l}\text { LKR.25,000- } \\
\text { LKR.50,000 }\end{array}$ & 81 & 46 & 61 & 66 \\
$\begin{array}{l}\text { More than LKR. } \\
\text { 50,000 }\end{array}$ & 6 & 4 & 3 & 5 \\
\hline
\end{tabular}

Source: Field survey, 2020

\section{Characteristics of home gardening}

\section{Crop types chosen to grow}

Figure 03 highlights the different crop types that the respondents cultivated in their home gardens during lockdown times.

Figure 03. Crops grown in lockdown home gardening

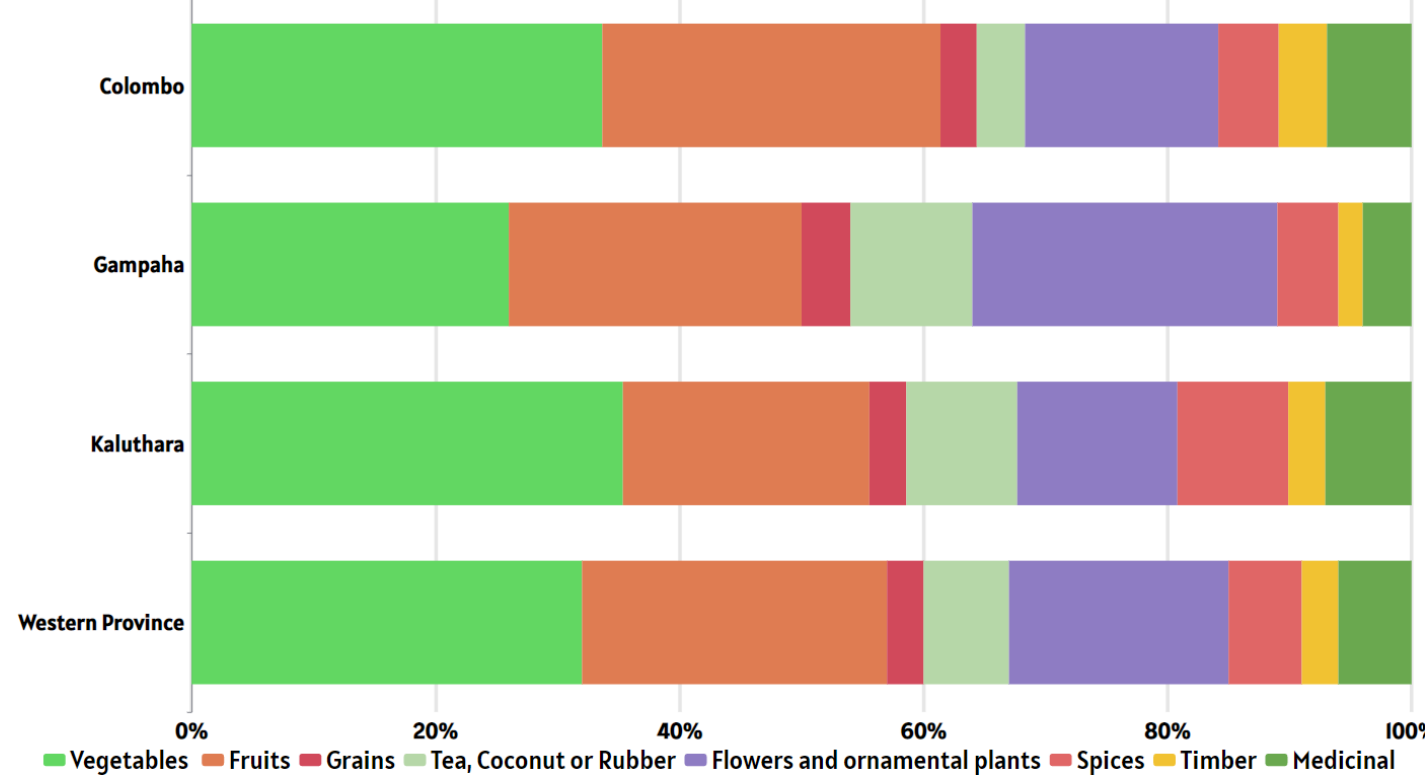

Source: Field survey, 2020 


\section{Original Article}

The majority in all three districts (34\% in Colombo, 26\% in Gampaha and 35\% in Kaluthara) have chosen to grow vegetables in their home gardens. This amounts to $32 \%$ of total respondents in the Western Province. Growing fruits is the second most popular choice ranging the percentages from $20-25 \%$ of respondents. Non-edible crops such as flowers and ornamental plants were also popular in all three districts. Respondents have also grown crops such as grains, spices, tea, coconut or rubber (at non-estate level) medicinal, and timber, but to a lesser extent.

\section{Extents of home gardens}

As indicated in Table 05 , only $31.2 \%$ of respondents of the Western Province had residential lands less than ten perches, out of which the majority of them were from the Colombo district. $68.8 \%$ of respondents in the Western Province had residential lands larger than ten perches, including those of 40 perches or more. Only $3-4 \%$ of respondents invariably in the Western Province had stated that they have no remaining land to grow after constructing the house. 69\% from Colombo, 56\% from Gampaha and 55\% from Kaluthara respondents had more than one-fifth of their land remains as garden area after constructing the house.
Table 05. Extents of home gardens in cultivation

\begin{tabular}{|c|c|c|c|c|}
\hline $\begin{array}{l}\text { Extents of } \\
\text { home garden } \\
\text { premises }\end{array}$ & 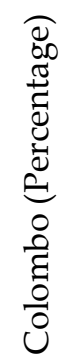 & 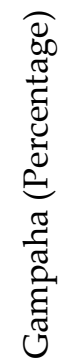 & 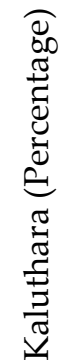 & 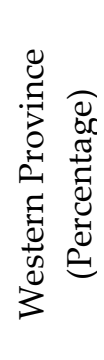 \\
\hline
\end{tabular}

Total extent

\begin{tabular}{|c|c|c|c|c|}
\hline less than $10 \mathrm{P}$ & 42 & 25.24 & 15 & 31.2 \\
\hline 10.1 P - 20 P & 43 & 33.50 & 38 & 39.5 \\
\hline $20.1 \mathrm{P}-30 \mathrm{P}$ & 7 & 13.59 & 13 & 10.3 \\
\hline $30.1 \mathrm{P}-40 \mathrm{P}$ & 3 & 7.28 & 9 & 5.5 \\
\hline Above $40.1 \mathrm{P}$ & 5 & 20.39 & 25 & 13.5 \\
\hline $\begin{array}{l}\text { Approximate } \\
\text { percentage of } \\
\text { land available } \\
\text { for cultivation } \\
\text { without built- } \\
\text { up area }\end{array}$ & & & & \\
\hline More than & & & & \\
\hline $\begin{array}{l}75 \% \text { of total } \\
\text { land extent }\end{array}$ & 3 & 2 & 10 & 4 \\
\hline $\begin{array}{l}\text { Between 51\% - } \\
75 \%\end{array}$ & 18 & 12 & 13 & 15 \\
\hline $\begin{array}{l}\text { Between 35\% - } \\
50 \%\end{array}$ & 27 & 12 & 11 & 19 \\
\hline $\begin{array}{l}\text { Between 21\% - } \\
34 \%\end{array}$ & 21 & 30 & 21 & 23 \\
\hline $\begin{array}{l}\text { Between } 01 \% \text { - } \\
20 \%\end{array}$ & 28 & 41 & 42 & 35 \\
\hline $\begin{array}{l}\text { Zero vacant } \\
\text { space to } \\
\text { cultivate }\end{array}$ & 3 & 3 & 4 & 4 \\
\hline
\end{tabular}

Source: Field survey, 2020

\section{Space Management}

Residential property utilisation for home gardening in the Western Province (Figure 04) highlights those residents have used both indoor (builtup area) and outdoor garden spaces for 


\section{Original Article}

their growing activities. 83\% of respondents in the Colombo district have used some of their indoor spaces (within the perimeter of the built-up area) for growing purposes -pots and bags in balcony, pavement or rooftop areas. The same pattern was observed in the Gampaha and Kaluthara districts. Fences as a space to grow are also used in all districts. Only $12 \%$ of respondents from Western Province (in other words, 7\% from Colombo, 18\% from Gampaha and 16\% from Kaluthara) reported that the space utilisation for home gardening was limited to outdoor garden spaces only.

Figure 04. Cultivation spaces of home gardens

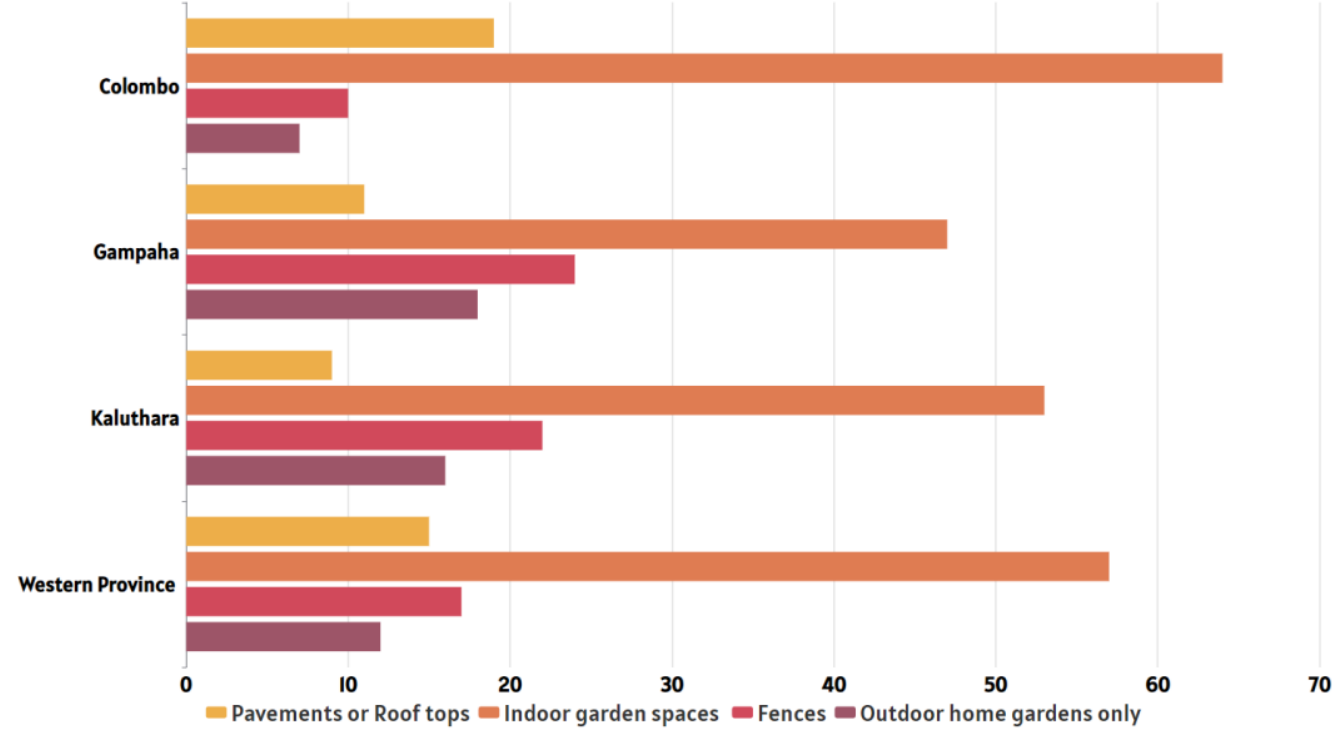

Source: Field survey, 2020

\section{Fertiliser usage}

A noticeable feature according to Figure 05 is that almost all the respondents in the Western Province have been applying compost and organic fertiliser for home gardening during lockdown times. A few respondents, i.e., a total of $14 \%$ in
Western Province representing 11\% from Colombo, 19\% from Gampaha and $14 \%$ from Kaluthara have applied a mix of compost and chemical fertiliser. The respondents who depended solely on chemical fertiliser were very small and almost negligible compared to those who apply organic fertiliser. 


\section{Original Article}

Figure 05. Application of fertiliser for home gardening

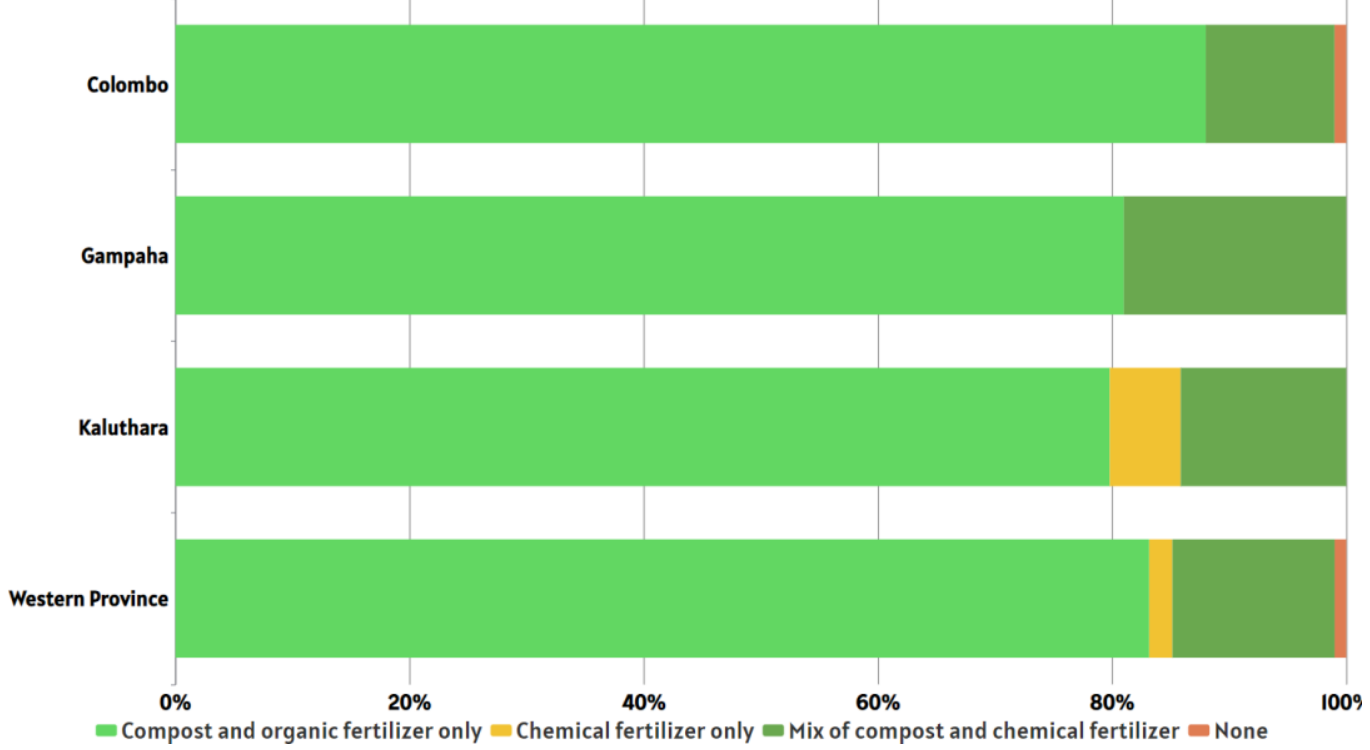

Source: Field survey, 2020

\section{Crop output}

Figure 06 highlights the approximate crop output levels that the respondents obtained during lockdown home gardening.

Figure 06. Crop output from lockdown home gardening

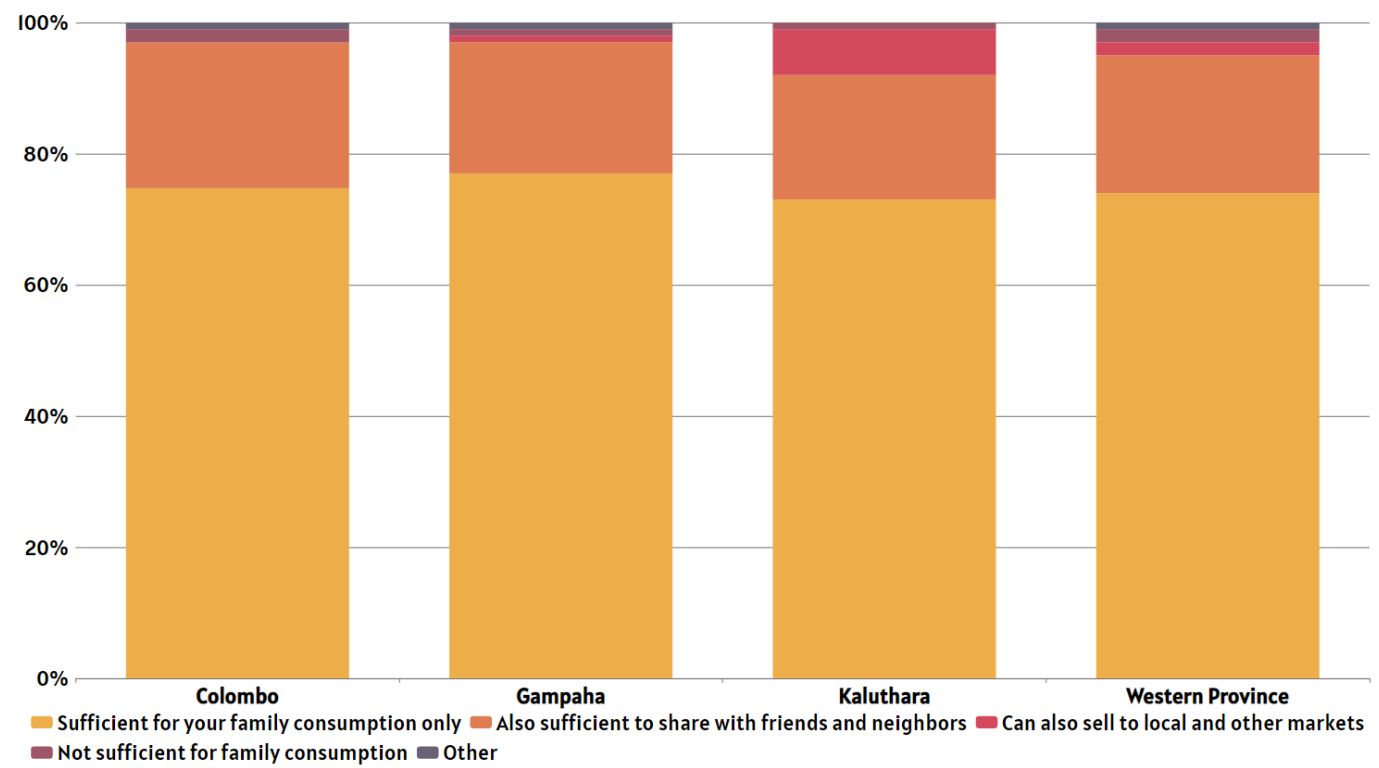

Source: Field survey, 2020

Approximately, during the five months' period of cultivation (3 months' period of complete lockdown and two months' period of gradual normalising of the Western Province), 97\% of cumulative total respondents in all three districts have been able to receive crop outputs sufficiently 


\section{Original Article}

supplementing their family consumption. $21 \%$ of respondents in the Western province had sufficient crop outputs even to share between friends and neighbours. This has been more or less indifferent among the three districts $-22 \%$ of respondents in Colombo, $20 \%$ of respondents in Gampaha, and 19\% of respondents in Kaluthara have been sharing crops with family and neighbours. Relatively fewer number of respondents in Gampaha (1\%) and Kaluthara (7\%) districts have been able to receive outputs sufficient enough to sell locally. However, on average, $2 \%$ of respondents in the Western Province have been unsuccessful in terms of receiving crops at least fulfilling their family needs.

\section{Benefits, Challenges and Suggestions to improve home gardening}

\section{Benefits expected from lockdown home gardening}

'Getting access to healthy food' was the primary response of households of all districts with respect to their anticipated benefits from lockdown home gardening (Figure 7).

Figure 07. Benefits expected from Lockdown Home Gardening

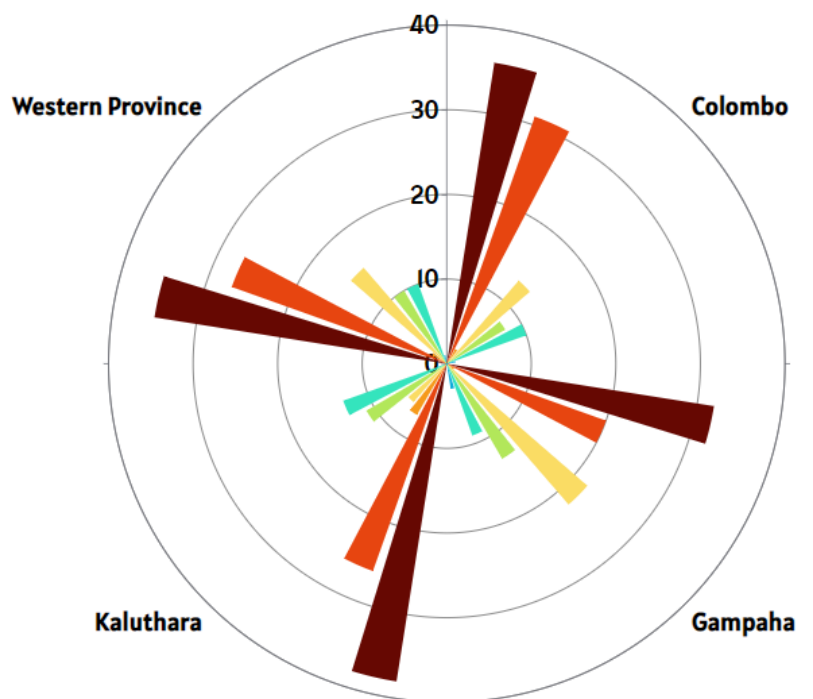

Eat healthy and tasty foods Save more money/reduce monthly expenditure on food

As a self-employment/Small scale business to earn extra income For relaxation, health and leisure Beautification of the home

Better green environment around the house $=$ Increasing property value (having timber trees etc.)

Source: Field survey, 2020

The response rate for this is 35\% from the Western Province whilst this average comprises of $36 \%$ from Colombo, 32\% from Gampaha and 38\% from Kaluthara. The next highest benefit expected out of lockdown home gardening was to save money or reduce monthly food expenditure. This was expected by $27 \%$ of total respondents, which comprises 31\% from Colombo, $20 \%$ from Gampaha and 26\% from Kaluthara. Further, $15 \%$ of total respondents thought lockdown home gardening provides leisure, relaxation, 


\section{Original Article}

and stress relief activity. Around 10\% of respondents believed that home gardening could be beneficial to beautify their homes and increase the green environment around their living areas. In Kaluthara District, $07 \%$ of respondents mobilised home gardening as a self-employment opportunity. Moreover, $03 \%$ of respondents in the Gampaha district expected that home gardening could increase their residential property values. On average, those who anticipate this benefit was $01 \%$ of total respondents.

\section{Challenges for lockdown home gardening}

Having the Likert scale responses, the analysis with respect to challenges that the households' faced in lockdown home gardening was performed through mean values and standard deviations (Table 09). A mean score reported to be higher than 1.7 considered to be an indicator of perceived challenge. As far as the Western Province aggregate figures are concerned, difficulty in accessing growing materials such as plants and seeds during lockdown times, lack of knowledge, pests, diseases and threats from animals in suburban areas (e.g. rats, wild boar, porcupines, monkeys etc.), lack of top soil fertility, maintenance hassle and vandalising scored highest mean scores [higher than 1.7] with relatively lowers standard deviation [less than 1.0]. A comparison of mean scores among all three districts shows that challenges are perceived to be highly critical in the Kaluthara district. Except for two factors: land size and little sunlight, all other challenging factors scored a mean value higher than 1.70 .

Table 06. Resident's perception of challenges for home gardening

\begin{tabular}{|c|c|c|c|c|c|c|c|c|c|c|c|c|}
\hline \multirow[b]{2}{*}{$\begin{array}{l}\text { Challenges \& } \\
\text { Disadvantages }\end{array}$} & \multicolumn{3}{|c|}{ Colombo } & \multicolumn{3}{|c|}{ Gampaha } & \multicolumn{3}{|c|}{ Kaluthara } & \multicolumn{3}{|c|}{ Western Province } \\
\hline & $=$ & $\overbrace{\Sigma}^{\varpi}$ & $\begin{array}{l}\vec{े} \\
\text { صं } \\
\text { के }\end{array}$ & $=$ & $\overbrace{\Sigma}^{\varpi}$ & $\begin{array}{l}\vec{\nu} \\
\text { Dें } \\
\text { के }\end{array}$ & $\approx$ & $\sum_{\Sigma}^{\Xi}$ & $\begin{array}{l}\vec{\nu} \\
\dot{0} \\
\dot{\vec{\omega}}\end{array}$ & 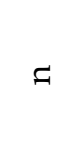 & $\sum_{\pi}^{\approx}$ & $\begin{array}{l}\text { 己े } \\
\text { कें }\end{array}$ \\
\hline $\begin{array}{l}\text { Available land } \\
\text { extent for } \\
\text { cultivation is } \\
\text { too } \\
\text { small/inadequ } \\
\text { ate }\end{array}$ & 459 & 1.01 & .749 & 254 & 1.04 & .774 & 226 & 1.16 & .797 & 939 & 1.06 & .769 \\
\hline $\begin{array}{l}\text { Difficult to get } \\
\text { necessary } \\
\text { plants/seeds to } \\
\text { grow }\end{array}$ & 459 & 1.88 & .754 & 254 & 1.77 & .713 & 226 & 2.27 & .675 & 939 & 1.94 & .748 \\
\hline $\begin{array}{l}\text { Lack of } \\
\text { knowledge/ad } \\
\text { equate } \\
\text { information/g }\end{array}$ & 459 & 1.88 & .755 & 254 & 1.74 & .642 & 226 & 2.15 & .589 & 939 & 1.91 & .703 \\
\hline
\end{tabular}




\section{Original Article}

\begin{tabular}{|c|c|c|c|c|c|c|c|c|c|c|c|c|}
\hline $\begin{array}{l}\text { uidance to } \\
\text { cultivate }\end{array}$ & & & & & & & & & & & & \\
\hline $\begin{array}{l}\text { Problems with } \\
\text { pests and } \\
\text { diseases }\end{array}$ & 459 & 1.76 & .679 & 254 & 1.86 & .719 & 226 & 2.28 & .651 & 939 & 1.91 & .714 \\
\hline $\begin{array}{l}\text { Problems with } \\
\text { other } \\
\text { (sub)urban } \\
\text { wildlife } \\
\text { (monkeys/porc } \\
\text { upines/wild } \\
\text { boar/rats etc.) }\end{array}$ & 459 & 1.75 & .737 & 254 & 1.67 & .711 & 226 & 2.15 & .751 & 939 & 1.82 & .756 \\
\hline $\begin{array}{l}\text { Lack of soil } \\
\text { fertility }\end{array}$ & 459 & 1.7 & .659 & 254 & 1.57 & .69 & 226 & 2.15 & .663 & 939 & 1.77 & .703 \\
\hline $\begin{array}{l}\text { Hassle in } \\
\text { maintenance } \\
\text { of cultivation }\end{array}$ & 459 & 1.61 & .649 & 254 & 1.6 & .625 & 226 & 2.15 & .708 & 939 & 1.74 & .697 \\
\hline $\begin{array}{l}\text { Lack of } \\
\text { security to the } \\
\text { cultivation/va } \\
\text { ndalising }\end{array}$ & 459 & 1.59 & .669 & 254 & 1.58 & .653 & 226 & 2.11 & .694 & 939 & 1.71 & .707 \\
\hline $\begin{array}{l}\text { Lack of } \\
\text { drainage } \\
\text { facilities/water } \\
\text { logging of the } \\
\text { land }\end{array}$ & 459 & 1.65 & .742 & 254 & 1.39 & .649 & 226 & 2.01 & .751 & 939 & 1.67 & .753 \\
\hline $\begin{array}{l}\text { Shape of the } \\
\text { land is not } \\
\text { suitable for } \\
\text { cultivation }\end{array}$ & 459 & 1.49 & .659 & 254 & 1.49 & .64 & 226 & 2.06 & .763 & 939 & 1.63 & .722 \\
\hline $\begin{array}{l}\text { Cost of } \\
\text { cultivation } \\
\text { (fertiliser, } \\
\text { water, care } \\
\text { taker fee etc.) } \\
\text { is not } \\
\text { affordable }\end{array}$ & 459 & 1.46 & .616 & 254 & 1.45 & .625 & 226 & 2.08 & .704 & 939 & 1.61 & .694 \\
\hline $\begin{array}{l}\text { Not enough } \\
\text { sunlight to the } \\
\text { home garden }\end{array}$ & 459 & 1.5 & .618 & 254 & 1.5 & .652 & 226 & 1.5 & .824 & 939 & 1.6 & .702 \\
\hline $\begin{array}{l}\text { Dust, fumes } \\
\text { coming from } \\
\text { main roads are } \\
\text { damaging the } \\
\text { plants/fruits }\end{array}$ & 459 & 1.49 & .618 & 254 & 1.42 & .628 & 226 & 1.98 & .715 & 939 & 1.59 & .681 \\
\hline $\begin{array}{l}\text { No sufficient } \\
\text { physical } \\
\text { strength/disabi } \\
\text { lity of family }\end{array}$ & 459 & 1.42 & .606 & 254 & 1.43 & .617 & 226 & 1.74 & .765 & 939 & 1.5 & .663 \\
\hline
\end{tabular}




\section{Original Article}

\begin{tabular}{|c|c|c|c|c|c|c|c|c|c|c|c|c|}
\hline $\begin{array}{l}\text { members, } \\
\text { difficult to } \\
\text { engage in } \\
\text { cultivation }\end{array}$ & & & & & & & & & & & & \\
\hline $\begin{array}{l}\text { Difficulty in } \\
\text { accessing } \\
\text { water }\end{array}$ & 459 & 1.44 & .589 & 254 & 1.36 & .572 & 226 & 1.96 & .742 & 939 & 1.54 & .668 \\
\hline $\begin{array}{l}\text { Infections } \\
\text { disease risk } \\
\text { (eg: rat } \\
\text { fever/leptospir } \\
\text { osis) / } \\
\text { chemical } \\
\text { toxicity etc. }\end{array}$ & 459 & 1.44 & .608 & 254 & 1.33 & .57 & 226 & 1.99 & .718 & 939 & 1.54 & .676 \\
\hline $\begin{array}{l}\text { Contaminated } \\
\text { water table } \\
\text { due to } \\
\text { pollutants/was } \\
\text { te water } \\
\text { discharge } \\
\text { from nearby } \\
\text { properties }\end{array}$ & 459 & 1.42 & .598 & 254 & 1.35 & .597 & 226 & 1.96 & .723 & 939 & 1.53 & .674 \\
\hline $\begin{array}{l}\text { Soil } \\
\text { contamination } \\
\text { (eg: heavy } \\
\text { metal } \\
\text { contamination }\end{array}$ & 459 & 1.41 & .566 & 254 & 1.31 & .565 & 226 & 1.92 & .723 & 939 & 1.51 & .652 \\
\hline
\end{tabular}

(3-point Likert Scale: $1=$ challenge is not relevant, $2=$ challenge is relevant, and $3=$ challenge is highly relevant)

Cronbach Alpha (reliability value) of 0.966

Source: Field survey, 2020

\section{Households' suggestion to maintain the home gardening momentum}

The content analysis of the resident's suggestions to excel lock down home gardening towards home gardening of all times are shown in Table 07. Households considered addressing four main points: promoting healthy lifestyles, innovations in home gardening techniques, effective connection between residents and government officials for local agriculture and integrated policy and practice, which are important to make a positive influence to retain the momentum of lockdown home gardening even under new normal conditions.

Table 07. Resident's suggestion to improve home gardening as a part of Urban Agriculture in Western Province

\begin{tabular}{ll}
\hline Theme & Example of a response \\
\hline Promote & "Motivate and promote home \\
healthy & gardening in mass media and \\
lifestyles & various other means." \\
\hline Effective & "Authorities can introduce \\
connection & innovative methods that \\
between & households can use in urban \\
residents & areas for home gardening." \\
\hline
\end{tabular}




\section{Original Article}

\begin{tabular}{|c|c|}
\hline \multirow{5}{*}{$\begin{array}{l}\text { and } \\
\text { governmen } \\
t \text { officials } \\
\text { for local } \\
\text { agriculture }\end{array}$} & $\begin{array}{l}\text { "Promote organic fertiliser usage } \\
\text { and a healthy lifestyle among } \\
\text { households" }\end{array}$ \\
\hline & $\begin{array}{l}\text { "Provide households with more } \\
\text { knowledge on home gardening" }\end{array}$ \\
\hline & $\begin{array}{l}\text { "Government officials in local } \\
\text { areas for agriculture should } \\
\text { connect more with local } \\
\text { households" }\end{array}$ \\
\hline & $\begin{array}{l}\text { "Introduce a Mobile Application } \\
\text { with a system to supervise advise } \\
\text { and communicate with the house } \\
\text { gardeners." }\end{array}$ \\
\hline & $\begin{array}{l}\text { "Arranging a system to purchase } \\
\text { the harvest by the Government or } \\
\text { Private Sector. (Eg. Cooperative } \\
\text { System)" }\end{array}$ \\
\hline \multirow{3}{*}{$\begin{array}{l}\text { Local } \\
\text { planning } \\
\text { policies in } \\
\text { support of } \\
\text { home } \\
\text { gardening }\end{array}$} & $\begin{array}{l}\text { "Provide necessary technology, } \\
\text { infrastructure, and seeds" }\end{array}$ \\
\hline & $\begin{array}{l}\text { "Introduce new policies and } \\
\text { regulations in development plans } \\
\text { to promote Urban Agriculture" }\end{array}$ \\
\hline & $\begin{array}{l}\text { "UDA can be the intermediate } \\
\text { organisation to coordinate } \\
\text { between house / land owner and } \\
\text { buyers / suppliers since UDA has } \\
\text { the databases. This can be } \\
\text { introduced to some lands where } \\
\text { buildings are not permitted. To } \\
\text { encourage cultivating such lands } \\
\text { UDA can allow a small house to } \\
\text { be built in those lands within a } \\
10 \% \text { of land area. When there is } \\
\text { a house people usually tends to } \\
\text { cultivate as in a home garden." }\end{array}$ \\
\hline
\end{tabular}

Source: Field survey, 2020

\section{DISCUSSION}

The study aimed at understanding the lockdown home gardening landscape in the Western Province via three broad categorisations: (i) gardener characteristics, (ii) gardening characteristics and (iii) benefits, challenges of lockdown home gardening and suggestions to get potential for urban agriculture via lockdown home gardening.

Home gardening had been a practiced notion among the majority of the participants even before lockdown times. The lockdown has intensified that trend by adding new households into home gardening. Besides, the majority of the participants who were already in to home gardening wanted to increase their level of engagement. The households who were in complete non-welcoming of home gardening was a very little. The participants' family sizes were primarily 4-6 members spending around LKR 25,00050000/- (USD 138 - 277 equivalent) for food per month. The study did not observe their age, education, and occupation, and gender has become a dividing line for them to engage in home gardening. These findings tally with a significant number of recent studies (e.g., Mullins et al., 2021, Sofo and Sofo, 2020, Corley et al., 2021, Talidong and Toquero, 2020, Dissanayake and Dilini, 2020).

By engaging in home gardening during lockdown times, households' primary expectations were getting access to healthy food and saving money that they would spend on purchasing food otherwise. Conform to these motives, the fertiliser application for home gardening almost was based on organic types whilst the widely grown crop types were vegetables and fruits. Up to some extent, households also recognised that home gardening during lockdown times provides them 


\section{Original Article}

certain environmental benefits such as relaxation, leisure, beatification of homes and better green environment. These expectations were more or less consistent among all three districts in the Western Province and support previous work such as (Corley et al., 2021; Mullins, et al., 2021; Dissanayake and Dilini, 2020; Galhena et al., 2013; Calvet-Mir et. al., 2012; Buchmann, 2009; Kehlenbeck and Maass, 2004). There was also limited evidence that the idea of growing timber in gardens would increase property values. That home gardening products can generate extra income was also a stimulating factor for some.

Even though it was relatively to a lesser extent, participants who chose to grow flowers and ornamental plants, grains, spices, tea, coconut or rubber (at nonestate level) medicinal, and timber were in conformity with these latter motives.

Even though the Western Province is the most urbanised region in the country and the scarcity of land per se would be a fact, home gardening isn't seemingly being restricted by that. Whilst some had residential lands sufficient enough to retain spacious outdoor gardens (plots of land of 40 or 30 perches or more), residents' with smaller plots also had managed space to grow. Besides, with residential plots having open spaces around built-up area, participants have been employing space management strategies such as using vertical spaces such as fences, using pots and grow-bags to cultivate plants in indoor areas such as pavements, rooftops etc. Under these conditioned space inputs, the participants from all three districts had managed to receive crop outputs during lockdown times sufficient enough for their own consumption and to share with friends and neighbours. A limited number of participants had also experienced farthermost outcomes: have been able to earn extra income out of home gardening or no crops received even enough for family consumption.

Participants from all three districts reported that the home gardening was undertaken subject to some barriers. These were particularly overwhelming for the Kaluthara district. Some challenges, such as difficult to get necessary plants or seeds to grow were more lockdown bound. But other reported challenges inform that policies and initiatives that intend to support home gardening as a part of urban agriculture should pay attention to areas such as pest and disease control, gardeners provided with required knowledge, measures to retain and improve soil fertility in local neighbourhood areas and improve social values. A number of suggestions were also highlighted by participants and those more broadly are promoting healthy lifestyles, effectively connecting government officials for agriculture with local residents, local planning policies to be supportive of home gardening. 


\section{Original Article}

\section{CONCLUSION}

By providing evidence from the Western Province of Sri Lanka to understand the landscape of lockdown home gardening under three main aspects: gardener; home gardening; and benefits, challenges and suggestions to improve home gardening, the paper top up the empirical sub arena of lockdown home gardening. This contributes to COVID19 and home gardening literature in particular, and urban agriculture and sustainable communities (SDG 11) literature in general. The findings of the study is in accordance with most of the recent studies. The lockdown situation has intensified home gardening in the Western province through initiation or re-initiation of gardening activities. Home gardening has been an act of all classes having no dividing lines as far as households' socio-economic backgrounds are concerned. Primarily lead by the idea that home gardening is linked with good consumption and health, households had sufficient economically, socially and environmentally interwoven motivations to engage with it and receive reasonable level of output at least sufficient to own family consumption. The propensity to use organic fertiliser is another highlight presented by data.

The fact of land scarcity amidst urbanisation doesn't seemingly a limiting factors for home gardening in Western province. But to get acceleration of home gardening towards urban agriculture, households perceive that what is more important to look at from policy wise would be (i) promoting healthy lifestyle to retain the re-gained home gardening trend (ii) government officials appointed locally for agriculture to connect well with the local residents to provide advocacy on gardening, dealing with pest, repelling and tackling of urban wildlife etc. (iii) local planning policies supportive of home gardening particularly on local infrastructure that support to retain soil fertility. Carrying out longitudinal studies would merit to investigate the continuation level of lockdown home gardening in the new normal scenario and gain more insights on how these lockdown trends can be harnessed to promote urban agriculture in the Western Province.

\section{Acknowledgement}

The authors would like to acknowledge the support given by the CRES (Center for Real Estate Studies), Department of Estate Management and Valuation University of Sri Jayewardenepura Sri Lanka.

\section{References}

Abebe, T. and Mulu, D. (2017). The Role of Women in the Management and Utilisation of Home Garden: The Case of Dale District, in Southern Ethiopia. Asian Journal of Plant Science and Research. 7(4): 41-54.

Adekunle, O. O. (2014). An Investigation of Challenges Facing Home Gardening Farmers in South Africa: A Case Study of Three Villages in Nkokonbe Municipality Eastern Cape Province. 


\section{Original Article}

Journal of Agricultural Science. 6(1): 102104.

Allen, M. (2017). Sampling, Internet. In: The SAGE Encyclopedia of Communication Research Methods. SAGE Publications.

Al-Mayahi, A., Al-Ismaily, S., Gibreel, T., Kacimov, A. and Al-Maktoumi, A. (2019). Home gardening in Muscat, Oman: Gardeners' practices, perceptions and motivations. Urban Forestry \& Urban Greening. 38(1): 286-294.

Altieri , M. A. and Nicholls, C. I. (2020). Agroecology and the reconstruction of a post COVID-19 agriculture. The Journal of Peasant Studies. 47(5): 881-898.

Badami, M.G. and Ramankutty, N. (2015). Urban agriculture and food security: A critique based on an assessment of urban land constraints. Global Food Security.4(1): 8-15.

Bidarbakhtnia, A. (2020) . Surveys Under Lockdown; a pandemic lesson. United Nations Economic and Social Commission for Asia and the Pacific. (23), 1-7. https://www.unescap.org/resources/stat s-brief-april-2020-issue-no-23-surveysunder-lockdown-pandemic-lesson.

Buchmann, C. (2009). Cuban Home Gardens and Their Rolein Social-Ecological Resilience. Hum Ecology. 37(6): 705-721.

Bushamuka, V. N., de Pee, S., Talukder, A., Kiess, L., Panagides, D., Taher, A. and Bloem, M. (2005). Impact of a homestead gardening program on household food security and empowerment of women in Bangladesh. Food and Nutrition Bulletin. 26(1):17-25.

Calvet-Mir, L., Gómez-Bagetthun, E. and Reyes-García, V. (2012). Beyond food production: Ecosystem services provided by home gardens. A case study in Vall Fosca, Catalan Pyrenees, Northeastern Spain. Ecological Economics. 74(1): 153160.

Central Bank of Sri Lanka. (2019). Economic \& Social Statistics of Sri Lanka. Colombo. https://www.cbsl.gov.lk/sites/default/file s/cbslweb_documents/statistics/otherpu b/ess_2019_e.pdf.
Corley, J., Okely, J., Taylor, A., Page, D., Welstead, M., Skarabela, B., Redmond, P., Cox, S. R. and Russ, T. C. (2021). Home garden use during COVID-19: Associations with physical and mental wellbeing in older adults. Journal of Environmental Psychology. 73: 101545.

Department of Census and Statistics Sri Lanka. (2012). Highlights: Census of Population and Housing 2012, Western Province. http://www.statistics.gov.lk/pophousat/ cph2011/index.php?fileName=Western\& $\mathrm{gp}=$ Activities\&tpl=3.

Department of Government Information. (2020). Declaration of Police Curfew Island wide. Foreign Ministry - Sri Lanka. https://mfa.gov.lk/declaration-of-policecurfew-island-wide/

Department of Meteorology. (2021). Climate of Sri Lanka.

https://meteo.gov.lk/index.php?option=c om_content\&view=article\&id=94\&Itemi $\mathrm{d}=310$ \&lang $=\mathrm{en}$

Dissanayake, L. and Dilini, S. (2020). COVID-19 Outbreak and Urban Green Space, Food Security, and Quality of Life: Case of Urban Home Gardens in Kandy, Sri Lanka. Open Journal of Social Sciences. 8(9): 185-197.

Fan, S. (2020). Preventing global food security crisis under COVID-19 emergency. International Food Policy Research Institute. https://www.ifpri.org/blog/preventingglobal-food-security-crisis-under-covid19-emergency

FAO. (2020). COVID-19: Our hungriest, most vulnerable communities face "a crisis within a crisis". http://www.fao.org/news/story/en/item/ 1269721/icode/?utm_source=twitter\&ut m_medium=social+media\&utm_campai $\mathrm{gn}=\mathrm{fao}$

Galhena, D. H. (2012). Home Gardens for improved food security and Enhanced livelihoods in Nothern Sri Lanka. file://C:/Users/HP/Downloads/Galhena _grad.msu_0128D_11680.pdf 


\section{Original Article}

Galhena, D. H., Freed, R. and Maredia, K. M. (2013). Home gardens: a promising approach to enhance household food security and wellbeing. Agriculture $\mathcal{E}$ Food Security. 2(1).2-8

Global Report on Food Crisis. (2020). Global Network Against Food Crises \& Food Security Information Network. https://docs.wfp.org/api/documents/WF $\mathrm{P}$ -

0000114546/download/?_ga=2.188134760

.1576162555.1620459642-

1462166889.1620459642

Gray, L., Guzman, P., Glowa, K. M. and Drevno, A. G. (2013). Can home gardens scale up into movements for social change? The role of home gardens in providing food security and community change in San Jose, California. Local Environment. Local Environment. 19(2): 187-203.

Helen Keller International. (2001). Initial findings from the 2000 Cambodia National Micronutrient Survey, Supporting document to the Micronutrient Workshop held on 20th February, 2001, in Phnom Penh, Kingdom of Cambodia. https:/camnut.weebly.com/uploads/2/0/ 3/8/20389289/2000mnsurvey.pdf

Hettiarachchi, D., Noordeen, N., Gamakaranage, C., Somarathne, E. A. R. B. D. and Jayasinghe, S. (2021). Ethical Responses to the COVID-19 PandemicLessons from Sri Lanka. Asian Bioethics Review. 13(2): 225-233.

Hoogerbrugge, I. and Fresco, L.O. (1993). Homegarden systems: agricultural characteristics and challenges. Gatekeeper series, no. 39, IIED, London. https://edepot.wur.nl/73745

Hossain, S. T. (2020). 'Impacts of COVID-19 on the agri-food sector: Food security policies of Asian productivity organisation members'. Journal of Agricultural Sciences - Sri Lanka. 15(2): 116-132.

Howard, P. L. (2006). Gender and social dynamics in swidden and homegardens in Latin America. In: Tropical
Homegardens: A Time-Tested Example of Sustainable Agroforestry. (Eds.). Kumar, B.M. and Nair, P.K.R. 159-163, Springer. Hoogerbrugge, I., \& Fresco, L. (1993). Homegarden systems: agricultural characteristics and challenges. Gatekeeper Series - Sustainable Agriculture Programme, International Institute for Environment and Development, 39,

23. http://library.wur.nl/WebQuery/wurpub s/fulltext/73745

Kehlenbeck, K. and Maass, B. L. (2004). Crop diversity and classification of home gardens in Central Sulawesi, Indonesia. Agroforestry Systems. 63(1): 53-62.

Lal, R. (2020). Home gardening and urban agriculture for advancing food and nutritional security in response to the COVID-19 pandemic. Food Security. 12(4): 871-876.

Mitchell, R. and Hanstad, T. (2004). Small homegarden plots and sustainable livelihoods for the poor. Food and Agriculture Organization of the United Nations. http://www.fao.org/3/j2545e/j2545e00.ht $\mathrm{m}$

Montefrio, M. J. F. (2020). Interrogating the "productive" home gardener in a time of pandemic lockdown in the Philippines. Food and Foodways. 28(3): 216-225.

Mullins, L., Charlebois, S., Finch, E. and Music, J. (2021). Home Food Gardening in Canada in Response to the COVID-19 Pandemic. Sustainability. 13(6): 3056.

Nifiez, V. (1987). Household Gardens: Theoretical and Policy Considerations. Agricultural Systems. 23(3): 167-186.

Niñez, V. (1985). Working at half-potential: Constructive analysis of home garden programmes in the Lima slums with suggestions for an alternative approach. Food and Nutrition Bulletin. 7(3): 1-9.

Philpott, S. M., Egerer, M. H., Bichier, P., Cohen, H., Cohen, R., Liere, H., Jha, S. and Lin, B.B. (2020). Gardener demographics, experience, and motivations drive differences in plant species richness and composition in 


\section{Original Article}

urban gardens. Ecology and Society. 25(4). 20-25

Ranjani and Joshi, R. (2017). The Role of Horticultural Crops in Enhancing Nutrient Security. International Journal of Current Microbiology and Applied Sciences. 6(9): $\quad 311-316$. https://doi.org/10.20546/ijcmas.2017.609. 039

Reyes-García, V., Vila, S., Aceituno-Mata, L., Garnatje, T., Jesch, A., Lastra, J.J., Parada, M., Rigat, M., Vallès, J. and Pardo-deSantayana, M. (2010). Gendered Homegardens: A Study in Three Mountain Areas of the Iberian Peninsula. Economic Botany. 64(3): 235-247.

R Nair, D., Rajmohan, V. and TM, R. (2020). Impact of COVID-19 Lockdown on Lifestyle and Psychosocial Stress - An Online Survey'. Kerala Journal of Psychiatry. 33(1): 1-6.

Robertson, C. (2013). The Role of Gender in Urban Agriculture: A Case Study of Cape Town's Urban and Peri-Urban Townships. https://atrium.lib.uoguelph.ca/xmlui/bits tream/handle/10214/7760/Robertson_Car olyn_201312_MSc.pdf?sequence=1

Rodrigo, M. (2020). Amid lockdown, Sri Lankans nurture their own oases through home gardening. Mongabay. https://news.mongabay.com/2020/05/am id-lockdown-sri-lankans-nurture-theirown-oases-through-home-gardening/

Rossi, R., Socci, V., Talevi, D., Mensi, S., Niolu, C., Pacitti, F., Di Marco, A., Rossi, A., Siracusano, A. and Di Lorenzo, G. (2020). COVID-19 Pandemic and Lockdown Measures Impact on Mental Health Among the General Population in Italy. Frontiers in Psychiatry. 11 https://www.frontiersin.org/articles/10.3 389/fpsyt.2020.00790/full

Sofo, A. and Sofo, A. (2020). 'Converting home spaces into food gardens at the time of Covid-19 quarantine: All the benefits of plants in this difficult and unprecedented period'. Human Ecology. 48 (1): 131-139.

Sue, V. M. and Ritter, L. A. (2012). Sampling. In: Conducting Online Surveys. SAGE
Publications Inc.

Soini, E. (2005). Changing livelihoods on the slopes of Mt. Kilimanjaro, Tanzania: Challenges and opportunities in the Chagga homegarden system. Agroforestry Systems. 64(2), 157-167. https://doi.org/10.1007/s10457-004-1023$\mathrm{y}$

Sunwar, S., Thornström, C.-G., Subedi, A., \& Bystrom, M. (2006). Home gardens in western Nepal: opportunities and challenges for on-farm management of agrobiodiversity. Biodiversity and Conservation. 15(13), 4211-4238. https://doi.org/10.1007/s10531-005-35760

Talidong, K. J. and Toquero, C. M. (2020). Philippine Teachers' Practices to Deal with Anxiety amid COVID-19. Journal of Loss and Trauma. 25(6-7): 573-579.

Tanner, K. (2018). Survey designs. In: Research Methods. Elsevier.

Taylor, J. R., Lovell, S. T., Wortman, S. E. and Chan, M. (2016). Ecosystem services and tradeoffs in the home food gardens of African American, Chinese-origin and Mexican-origin households in Chicago, IL. Renewable Agriculture and Food Systems. 32(1): 69-86.

Thaman, R. R. (1995). Urban food gardening in the Pacific Islands: a basis for food security in rapidly urbanising smallisland states. Habitat International. 19(2): 209-224.

Verma, A. K. and Prakash, S. (2020). Impact of Covid-19 on Environment and Society. Journal of Global Biosciences. 09(5):73527363. https://ssrn.com/abstract=3644567

Walljasper, C. and Polansek, T. (2020). Home gardening blooms around the world during coronavirus lockdowns. https://www.reuters.com/article/ushealth-coronavirus-gardensidUSKBN2220D3

Watson, J. W. and Eyzaguirre, P. B. eds. (2002). Home Gardens to In Situ Conservation of Plant Genetic Resources in Farming Systems..https://www.bioversityinternati onal.org/fileadmin/_migrated/uploads/t 


\section{Original Article}

x_news/Home_gardens_and_in_situ_co nservation_of_plant_genetic_resources_i n_farming_systems_753.pdf

Weerahewa, J., Hemachandra, D. and Roy, D. (2020). How Agri-food Chains in Sri Lanka Fared During the Stringent COVID-19 Control Measures? https://southasia.ifpri.info/2020/05/13/ho w-agri-food-chains-in-sri-lanka-faredduring-the-stringent-covid-19-controlmeasures/.

World Health Organization (WHO). (2020a). Naming the coronavirus disease (COVID19) and the virus that causes it. https://www.who.int/emergencies/disea ses/novel-coronavirus-2019/technicalguidance/naming-the-coronavirusdisease-(covid-2019)-and-the-virus-thatcauses-it

World Health Organization (2020b). Coronavirus disease 2019 (COVID-19) Situation Report - 72. https://apps.who.int/iris/bitstream/handl e/10665/331685/nCoVsitrep01Apr2020eng.pdf? sequence $=1 \&$ isAllowed $=y$

Yapa, L. G. (2018). Contribution of Home Gardens to household food security in Sri Lanka: A comparative study on wet zone and intermediate zone. Journal of Social Sciences and Humanities Review. 3(3): 124132.

Zasada, I., Weltin, M., Zoll, F. and Benninger, S. L. (2020). Home gardening practice in Pune (India), the role of communities, urban environment and the contribution to urban sustainability. Urban Ecosystems. 23(2): 403-417. 